\title{
O świętej przestrzeni, Stanisławie Vincenzie i Eliadem. Próba konfrontacji religioznawstwa z literaturą
}

About the sacred space, Stanislaw Vincenz and Eliade. Literature vs. religious studies: The confrontation attempt.

\author{
|Sylwia Iwanek
Uniwersytet Kardynała Stefana Wyszyńskiego
w Warszawie
}

Abstract: The article is a report of classes conducted with $\mathrm{PhD}$ students of literary studies devoted to the issue of the sacred space in Prawda starowieku by Stanisław Vincenz in relation to religious terms: homo religiosus, sacrum, profanum, cosmic religion, used by Mircea Eliade. The author undertook an attempt to read the literary text using the terminology of philosophy of religion. This confrontation exposed the new possibilities of interpreting Vincenz's prose, and revealed the potential of interdisciplinary approach to reading literature.

Key words: space, sacrum, homo religiosus, Eliade, Vincenz

Streszczenie: Artykuł stanowi relację z przeprowadzonych zajęć z doktorantami literaturoznawstwa poświęconych zagadnieniu świętej przestrzeni w Prawdzie starowieku Stanisława Vincenza w odniesieniu do terminów religioznawczych: homo religiosus, sacrum, profanum, religia kosmiczna, którymi posługiwał się Mircea Eliade. Autorka podjęła się próby odczytania tekstu literackiego za pomocą terminologii filozofii religii. Konfrontacja ta odsłoniła nowe możliwości interpretacyjne prozy Vincenza, a także ujawniła potencjał tkwiący w interdyscyplinarnym podejściu do czytania literatury.

Słowa kluczowe: przestrzeń, sacrum, homo religiosus, Eliade, Vincenz

\section{Kilka słów wprowadzenia}

Projektując zajęcia ze studentami filologii polskiej, podjęłam decyzję o poświęceniu ich zagadnieniu świętej przestrzeni w Prawdzie starowieku Stanisława Vincenza. Pomyślałam, że to dobra okazja do zapoznania słuchaczy z niektórymi poglądami pisarza oraz z jego postrzeganiem świata. Z lektury Vincenza płynie głęboka mądrość spojrzenia na otaczającą rzeczywistość. Był on bowiem człowiekiem o tożsamości topiczno a-topicznej: zanurzony w teraźniejszości, w świecie rzeczywistym, nieustannie otwarty na doświadczanie sfery sacrum. Jego postawa cechowała się otwartością nie tylko na drugiego człowieka, ale również na elementy transcendencji ujawniające się w świecie. Można rzec, iż był to autor, którego dzieło życia - tetralogia Na wysokiej połoninie - przekazuje czytelnikowi treści 
wykraczające poza ramy tradycyjnej literatury. Jednak zinterioryzowanie poglądów Vincenza na podstawie lektury czterech tomów może przysporzyć nieco kłopotów. Rzecz w tym, że jest to księga prezentująca nam nie tylko legendy i gawędy z wierchowin karpackich, ale również odsłaniająca przed nami wielką filozoficzno-religijną prawdę. Jeśli nie skłonimy czytelnika do szerszego i - co najważniejsze - głębszego spojrzenia na tekst, możemy pozostać przy stwierdzeniu, że $\mathrm{Na}$ wysokiej połoninie jest jedynie etnograficznym esejem, dzięki któremu poznać możemy górali Karpat Wschodnich - Hucułów. Zadałam sobie zatem pytanie: w jaki sposób pomóc czytelnikowi, w tym przypadku studentom filologii polskiej, w dotarciu do treści metafizycznych dzieła? Rozważania te doprowadziły mnie do filozofów religii, a konkretnie do Mircei Eliadego, którego badania religioznawcze pozwalają otworzyć i na nowo odczytać $\mathrm{Na}$ wysokiej połoninie. Chciałam zatem, aby studenci, przez lekturę Vincenza, poznali nie tylko elementy jego światopoglądu oraz postawy wobec świata, ale także - na drodze indukcji - dotarli do odkrycia i zrozumienia pojęć z zakresu filozofii religii, takich jak: religia kosmiczna, homo religiosus, sacrum. W trakcie zajęć studenci mieliby również możliwość konfrontacji teorii filozoficznej z praktyką literacką.

Myślę ponadto, że interdyscyplinarne podejście w czytaniu i analizowaniu Vincenza może być interesujące i odkrywcze. W trakcie przygotowania do zajęć i w czasie ich trwania słuchacze mają możliwość konfrontacji swojej wiedzy z zakresu literaturoznawstwa z terminologią filozoficzno-religioznawczą, potrafią dostrzec zbieżności idei powstałych na początku $\mathrm{XX}$ wieku, jednak w dwóch, zupełnie różnych, przestrzeniach geograficznych oraz w ramach odrębnych dyscyplin naukowych.

Zanim przejdę do metodycznego omówienia projektu ćwiczeń, chciałabym poświęcić chwilę autorowi Na wysokiej połoninie. Stanisław Vincenz jest pisarzem wciąż jeszcze mało znanym. Tymczasem dorobek znawcy Huculszczyzny jest niebagatelny zarówno pod względem naukowym - filozoficznym czy literaturoznawczym - jak i życiowym. Vincenz był człowiekiem o niezwykle szerokich horyzontach. Studiował m.in. psychologię, prawo, sanskryt. Jego tożsamość w dużej mierze ukształtowali górale Huculszczyzny: wychowany przez huculską niańkę Pałachnę od najwcześniejszych lat chłonął legendy i gawędy z wierchowin karpackich. To one kształtowały w nim otwartość na przyrodę i jej bogactwo, zaś obcowanie z drugim człowiekiem, nierzadko różnym pod względem kulturowym czy narodowym, wykształciło w nim to, co później odkrywał u starożytnych Greków - przekonanie, że każdy cudzoziemiec (gr. xeinos) to nie tylko obcy, ale przede wszystkim gość, którego należy przyjąć z otwartym sercem i dobrocią. Jest zatem Vincenz nauczycielem i mędrcem otwierającym przed nami prawdę o tym, że świat to nasz dom, w którym odnaleźć możemy nie tylko ślady dawnych epok, historii, ale również prawdę o rzeczywistości nadziemskiej, która nieustannie współgra ze sferą widzialną i namacalną. 


\section{O organizacji zajęć}

Spotkanie trwało 90 minut i zostało poprzedzone przygotowaniem $\mathrm{w}$ domu - lekturą fragmentu pierwszego tomu tetralogii Na wysokiej połoninie (Vincenz 2002, s. 43-52 i 57-60) oraz jednego rozdziału z książki Sacrum, mit, historia (Eliade 1970, s. 53-89). Teksty te doskonale odpowiadają potrzebom założonych celów: wiele mówią o relacji człowieka z przyrodą, co jest niezwykle istotne także w religii kosmicznej, oraz wskazują na różnego rodzaju tradycje i obrządki towarzyszące Hucułom podczas budowy domu (tutaj odnaleźć można zbieżności z koncepcją człowieka religijnego stworzonego przez rumuńskiego badacza). Warto również wskazać studentom, na jakie zagadnienia mają zwrócić szczególną uwagę podczas lektury fragmentów. Tekst Eliadego nie jest skomplikowany, jednak terminologia, którą się posługuje, może okazać się obca, co prawdopodobnie przysporzy nieco problemów w prawidłowym odczytaniu i zrozumieniu ich znaczenia. Kwestia, na którą również można zwrócić uwagę, to obszerność tekstów.

Trzeba podkreślić, że w przeprowadzeniu tego typu ćwiczeń dobrze jest posłużyć się metodą indukcyjną - najpierw słuchacze czytają i analizują tekst literacki, aby później wyniki tych działań skonfrontować z treściami filozoficznymi. Próba odwrotnego poprowadzenia zajęć może zakończyć się fiaskiem z kilku względów. Pierwszym z nich jest ograniczenie czasowe: jeżeli rozpoczniemy spotkanie od teoretycznego wprowadzania pojęć i analizowania terminów filozoficznych, istnieje prawdopodobieństwo, że zabraknie nam czasu na czytanie Vincenza. Poziom trudności i abstrakcji terminów religioznawczych jest znaczący, co może zakończyć się tym, że czas potrzebny na ich zrozumienie znacząco się wydłuży. Aby uniknąć tego niebezpieczeństwa, warto rozpocząć od czytania i analizy fragmentu z książki Vincenza. Ponadto są to zajęcia poświęcone twórczości znawcy Huculszczyzny, nie zaś Eliademu, zatem to utwór literacki powinien stać w centrum.

W mierzeniu się z literaturą i filozofią metoda indukcyjna może przynieść o wiele większe i trwalsze rezultaty. Wyprowadzanie uogólnień, hipotez z lektury tekstu literackiego oraz próba konfrontowania ich z terminami z filozofii religii jest drogą do lepszego zrozumienia pojęć zawartych w pracy Eliadego. Co więcej, konkret literacki będzie podstawą teoretycznego uogólnienia - to tekst prozaiczny stanie się egzemplifikacją trudniejszych, bardziej abstrakcyjnych kategorii filozoficznych (Kwiatkowska-Ratajczak 2002, s. 211).

\section{Przejdźmy do zajęć}

Opisywane zajęcia rozpoczęłam miniwykładem poświęconym sylwetce pisarza Stanisława Vincenza. Opowieść ta, w moim odczuciu, może zostać wzbogacona o zdjęcia: autora tetralogii oraz miejsc związanych z jego życiem - głównie rejony Stanisławowa i pasmo górskie Czarnohora. Krótki wykład zawierał podstawowe informacje dotyczące życia pisarza 
(szczególnie o przestrzeni, w której się wychował - pogranicze wielokulturowe oraz rejony górskie), a także stanowił prezentację niektórych przekonań i wartości, którymi kierował się w życiu. Uznałam za bardzo istotne, aby informacje te były nie tylko wprowadzeniem w świat autora tetralogii, ale również stały się zapowiedzią tego, o czym będzie mowa w późniejszej fazie zajęć. Zaprezentowałam zatem kilka głównych poglądów Vincenza na temat otaczającego świata (skupiłam się na zagadnieniu „pisma światowego” i miejsc - źródeł, tzw. „pępków”) oraz znaczenia, jakie przypisywał relacji człowiek - przyroda. Wyeksponowanie wspomnianych przekonań i wartości zwiększyło prawdopodobieństwo zapamiętania ich przez studentów oraz wykorzystania w późniejszej fazie zajęć. Celem tego wstępu było również rozbudzenie zainteresowania autorem tetralogii - zarówno jego życiem, jak i twórczością. Wykład zaintrygował studentów, na co wskazywali w trakcie końcowego omówienia zajęć - wymiany wrażeń, wniosków, sugestii.

Konfrontowanie filozofii religii z literaturoznawstwem może nieść pewne trudności, tym bardziej gdy wiemy, że uczestnicy zajęć nie mieli dotychczas styczności z pierwszą z wymienionych dziedzin nauki. Wiedza ta doprowadziła mnie do konstatacji, iż najlepszą drogą poprowadzenia zajęć jest forma warsztatowa. Formuła ta pozwala na większe zaangażowanie studentów oraz jest okazją do obserwacji pracy słuchaczy (Kostera, Rosiak 2008, 115). Myślę, że w tym przypadku sposób ten dał mi również możliwość uzyskania informacji, czy studenci rozumieją nowe pojęcia.

Po wprowadzeniu przeszłam do fazy głównej zajęć - analizy fragmentów Prawdy starowieku Stanisława Vincenza. Wybrałam rozdziały Chata oraz Trawy z części zatytułowanej Gazdowie, czyli opowiadającej o najstarszych dziejach świata górskiego. Proza autora tetralogii jest inkrustowana głęboką symboliką: każde działanie ludzkie ma swoje źródło w transcendencji, zaś otaczający świat postrzegany bywa jako echo sfery sacrum, odbicie rzeczywistości nadziemskiej. Spojrzenie to koresponduje z tym, o czym mówił Eliade - świętość objawia się w świecie, zazwyczaj w pewnej opozycji do profanum, „do pragmatycznego kontinuum powszedniości, objawia się jednak za pośrednictwem profanum" (Eliade 1970, 11).

\section{Filozofia religii a literaturoznawstwo}

W fazie głównej słuchacze zostali podzieleni na dwie grupy, które miały skupić się na pracy z tekstem Na wysokiej połoninie. Zadaniem pierwszej była analiza fragmentów opisujących przyrodę połonin (co objawia, jak jest kreowana, w jaki sposób budowane są przestrzeń i pojęcie czasu, jak przebiega relacja człowiek - natura), druga zaś skupić się miała na fragmencie związanym z budową domu przez Hucuła (w jaki sposób góral wybiera miejsce na budowę, jaka jest rola znaków, doświadczenia i czym jest dom dla mieszkańca połonin). Celem tego ćwiczenia była pogłębiona lektura 
i analiza tekstu Vincenza oraz próba wyprowadzenia z niego głównych założeń światopoglądu autora. Co więcej, studenci mogli również poznać świat Hucułów. W tej części zajęć czuwałam nad przebiegiem prac, sądzę jednak, że podane pytania naprowadziły studentów na poprawne tropy w odczytaniu treści lektury. Podczas gdy studenci mierzyli się z tekstem, narysowałam na tablicy tabelkę, która później posłużyła podsumowaniu pracy w grupach:

\begin{tabular}{|c|c|}
\hline STANISŁAW VINCENZ & MIRCEA ELIADE \\
\hline & \\
\hline
\end{tabular}

Taki prosty zapis miał stanowić dla nas formę notatki, w której znajdą się najważniejsze informacje na temat tego, o czym pisali Vincenz i Eliade. Aby przyjrzeć się dwóm aspektom, nad którymi studenci pracowali w grupach, trzeba sięgnąć po tekst pierwszego tomu tetralogii Prawda starowieku, a później uzupełnić je o poglądy rumuńskiego filozofa. Zobaczmy zatem, co mówi nam tekst prozaiczny na temat relacji człowieka z przyrodą. Czym ona dla niego jest? Jak Hucuł przygotowuje się do budowy domu? W jaki sposób wykreowany został świat karpackich wierchowin?

Był Vincenz niewątpliwie doskonałym słuchaczem, nie tylko drugiego człowieka, ale również otaczającej go przyrody. Cała tetralogia powstała dzięki opowieściom, jakie snuli Hucułowie wśród swoich sąsiadów i bliskich. Jest to, jak wskazuje podtytuł, zbiór legend i gawęd z połonin przekazywanych wśród górali z pokolenia na pokolenie. Stanisław Vincenz - jeden ze słuchaczy owych opowieści - napisał księgę niosącą mądrość patrzenia na rzeczywistość. Geograficzny zakątek, całe jego bogactwo naturalne i przyroda były naznaczone śladami nie tylko wcześniejszych pokoleń, ale również tych zostawionych przez Stwórcę. Ślady te nazwane zostały „pismem światowym”, pismem naszej duszy, które uważny człowiek jest w stanie odczytać. Relacja ludzi z otaczającym światem odznaczała się dynamizmem, dialogicznością. Człowiek gór był bowiem głęboko zanurzony w teraźniejszości, wychylając się jednocześnie ku wiecznemu trwaniu. Słowa Prawdy starowieku doskonale to obrazują: „Wejść i wyjść - oto skrót losu człowieczego" (Vincenz 2002, 48). Pojęcie czasu osadzone jest zarówno w tradycji chrześcijańskiej, jak i w mądrości ludowej. Z jednej strony objawia nam się jako „fala wieczności” (Vincenz 2002, 59), człowiek zaś jest niejako zanurzony w nim jedynie na chwilę, z drugiej widzimy, jak rytm życia, czas umierania i czas odradzania, wyznacza rytm przyrody. Góral jest nierozerwalnie złączony z naturą, od niej niejako zależny:

Dla najdawniejszych chat rąbano w puszczy kłody, ciosano je tamże, aby postawić dom w tym miejscu. Lecz choć wybrano i przygotowano budulec najlepszy, nikt nie wyrąbywał lasu od razu, tylko w ciągu lat. Bo takiemu co by wygolił las jak brodę, niespodzianie, nieraz w nocy, zalała wyrąb woda, co łakoma buchnąć ze źródła odkrytego rąbaniem. Tym mniej nikt nie stawiał od razu chaty na wyrębie. Naprzód 
trzeba długo badać, trza uczyć się, gdzie można wyrobić z lasu carynki sianokośne, gdzie ogrody a gdzie pastwiska (Vincenz 2002, 45).

Człowiek był zobowiązany do powolnego budowania swojego domostwa. Łączyło się to z przekonaniem, że otaczająca nas przyroda i świat to kosmos, pełnia, której niszczenie może zaburzyć również współżycie. Echa poglądu o harmonii świata dostrzec możemy w opisach przyrody skonstruowanych przez autora:

Szum lasu z dołu, z wierzchołka Kiczery, szum Czeremoszu ledwie dosłyszalny z głębi doliny - cisza, niebo i słońce górskie, a jako jedyne towarzystwo - stara wydeptana ścieżyna, wijąca się daleko. A jedyny ruch to pszczoły i trzmiele, niosące miłość kwiatom. A czasem dalekie dzwoneczki trzód z jakiegoś pastwiska, czasem kukanie zazuli, jakby sama wiosna siebie oznajmiała. (...) Nie ma zupełnie poczucia pustkowia ni zbytniego ogromu, jak to bywa w połoninach, a jednak rozległość wielka, niejednostajna, ciągle inna, zda się coraz piękniejsza. Ten świat łąk, carynek i kwietników gwiaździstych - to jeden świat bezpieczeństwa, ciszy, szczęścia (Vincenz 2002, 58).

Harmonia i ład są dla człowieka przestrzenią doświadczania pełni - hierofanii wskazującej na transcendencję. Przeciwstawia się temu świat obcy, nieznany, pełen niebezpieczeństw. Człowiek gór miał świadomość tego, iż istnieją obszary, które są kontrastem dla owego ładu. Chaos, bo tak możemy nazwać miejsca odległe i nieznane, objawia się tam, gdzie Hucuł jeszcze nie dotarł, gdzie świat i człowiek nie współgrają ze sobą, lecz istnieją, opierając się na zasadzie poddaństwa - natura jest tylko po to, aby służyć ludziom, aby oni mogli wyzyskiwać ją i niszczyć, jeśli taka jest potrzeba ekonomiczna.

Wspomniany wyżej brak pośpiechu w budowaniu domu wiąże się nierozłącznie z szacunkiem, jakim Huculi darzyli przyrodę. Drzewa były budulcem, jednak ich karczowanie rozciągało się w czasie: „Lecz choć wybrano i przygotowano budulec najlepszy, nikt nie wyrąbywał lasu od razu, tylko w ciągu lat" (Vincenz 2002, 45). Świadomość odnawialności przyrody skłaniała górala do czekania, włączenia się w ów rytm, aby natura nie została nadmiernie zniszczona, aby miała czas na odbudowanie. Potrzeba zaś budowy domu ściśle wiązała się z poszukiwaniem znaków, które wskazałyby najlepsze miejsce do stworzenia domostwa. Hucuł szukał bowiem śladów w przyrodzie zostawionych przez Stwórcę, będących wiadomością o przestrzeni, w której chciał zbudować dom:

Pokłonią się światy przed tak wielkim trudem i ofiarą. Pieśń daje nabożną pochwałę pracy i trudowi. Potwierdza śmiało, że tam, gdzie któryś z nas narażał głowę pod pioruny, pod lawinę, pod powódź i przeciw zwierzowi dzikiemu, gdzie trapił się, trudził i mozolił, zmagając się z puszczą, tam w istocie przed wiekami już wyprzedził go Syn Człowieczy, kroplę potu uronił, i naznaczył miejsce na chatę i dla budowania (Vincenz 2002, 44).

Mieszkaniec Karpat Wschodnich z nabożnością poszukiwał miejsc przez uważne wsłuchiwanie się w odgłosy przyrody: zwierząt, owadów, drzew. 
To one posiadały wiadomości od Boga. Gdy obszar taki został znaleziony, konieczne było spędzenie tam jednej nocy, aby sen, jaki się wówczas przyśni, potwierdził, czy nasłuchiwania odczytane zostały prawidłowo. Wszystkie te rytuały wyrażały również pogląd, że „co ma trwać długo, powstaje długo" (Vincenz 2002, 46), było to też swego rodzaju potwierdzenie, iż miejsce to staje się - wraz z wybudowaniem na nim domu - źródłem istnień ludzkich, „pępkiem”, które stanowi dla kogoś centrum, miejsce stałe.

Zebrane powyżej przykłady mogą stanowić próbkę tego, co wyczytać można z kart tetralogii. Również studenci, w trakcie analizy i interpretacji tekstu, dostrzegli owe aspekty. Zgromadziliśmy je w pierwszej z kolumn tabeli:

\begin{tabular}{|l|l|}
\hline \multicolumn{1}{|c|}{ STANISŁAW VINCENZ } & MIRCEA ELIADE \\
\hline 1. & Przyroda: \\
• czas - fala wieczności & \\
• przyroda i świat przedstawiony & \\
- jako kosmos & \\
- odnawialność i rytm natury & \\
- mięzek człowieka i ziemi & \\
i chaosu doświadczenia kosmosu & \\
• płodność ziemi & \\
2. Budowa domu: & \\
• miejsca objawione przez Stwórce & \\
• znaki - sen w miejscu, gdzie ma & \\
zostać zbudowany dom (jaki znak & \\
otrzyma człowiek) & \\
- miejsca: tzw. „środki”, tj. centra, & \\
źródła wszechświata pojedyn- & \\
czego człowieka lub całej rodziny, & \\
nazywane przez Vincenza „pęp- & \\
kami” (punkty stałe).
\end{tabular}

Ten etap zajęć zakończyłam ogólnym zreferowaniem i zebraniem w całość wszystkich informacji na temat świata wykreowanego przez Vincenza. Wraz ze studentami, w trakcie rozmowy, uporządkowaliśmy i utrwaliliśmy zdobytą wiedzę. Część ta pobudziła ciekawość uczestników zajęć. Nawiązałam również do treści, które pojawiły się we wstępie. Teoretyczne wówczas zagadnienia, jak chociażby „pismo światowe”, przerodziły się w konkret literacki.

Po podsumowaniu i omówieniu świata przedstawionego przez Vincenza przeszłam do próby określenia, czym jest religia kosmiczna i człowiek religijny. W tym celu każdy student dostał plik małych karteczek, na których wypisane były terminy związane z wyżej wymienionymi zagadnieniami:

1. religia kosmiczna

- natura

- $\operatorname{kosmos} \neq$ chaos 
- przestrzeń jednorodna i niejednorodna

- sacrum

- ziemia

- płodność

- odnowa

- pęknięcia, szczeliny

- $\quad$ świat = kosmos, miejsce ujawniania się sacrum

2. człowiek religijny

- życie według rytmu przyrody

- człowiek integralny

- objawienie, doświadczenie

- miejsca - „środki”

- punkty stałe

- wychylenie ku transcendencji, wieczności

Zadaniem każdego słuchacza była próba porządkowania zakresów znaczeniowych poszczególnych pojęć (w powyższym zestawieniu podałam prawidłowe pogrupowanie). Element ten stanowił punkt wyjścia do rozmowy najpierw na temat terminów stworzonych przez Eliadego, aby następnie połączyć je z tym, co proponuje Vincenz.

Słuchacze intuicyjnie wykonali ćwiczenie. Już w pierwszych chwilach omawiania wyników pracy pojawiły się skojarzenia z tym, co odkryliśmy $\mathrm{u}$ autora tetralogii. Widać bowiem $\mathrm{w}$ przytoczonym materiale pojęciowym echa Vincenzowego spojrzenia na rzeczywistość. Aby lepiej zobrazować przytoczone powyżej hasła, chciałabym sięgnąć po tekst Eliadego, próbując zarazem zestawić go z tym, co już powiedzieliśmy o świecie połonin.

Gdy spojrzymy na to, co udało nam się odkryć w trakcie lektury fragmentów tetralogii, nietrudno dostrzec, że kategorie związane z człowiekiem religijnym doskonale odpowiadają cechom charakteryzującym mieszkańca wierchowin karpackich. Jak zauważa Eliade:

Dla człowieka religijnego przestrzeń nie jest jednorodna; są w niej rozdarcia, pęknięcia: są fragmenty przestrzeni jakościowo różne od innych. (...) Jest więc obszar święty (Eliade 1970, 53).

Hucuł był niewątpliwie bardzo uważny w swoim obcowaniu z przyrodą i światem. Potrafił dostrzec miejsca, w których ziemia naznaczona była przez Stwórcę „kroplą potu”, która spadła, gdy wędrował przed wiekami po połoninach (Vincenz 2002, 44). Momenty odkrycia obszarów uświęconych traktował jako pewnego rodzaju objawienie, doświadczenie sfery sacrum. Przestrzeń wydawała mu się niejednorodna, gdyż w wielu miejscach dostrzegał przełamanie sfery profanum przez objawienie się świętości - doświadczenie hierofanii. Podejście takie doskonale koresponduje ze słowami Eliadego, który twierdził, że „niejednorodność przestrzeni znajduje wyraz $\mathrm{w}$ doświadczeniu przeciwieństwa, jakie zachodzi między obszarem ś wi ętym, jedynym rzeczywistym, tym, który istnieje realnie" 
(Eliade 1970, 53). Był zatem Hucuł nieustannie wychylony ku transcendencji, uważnie i nabożnie wręcz obserwował otaczający go świat. Odnajdując przestrzeń, w której stawiał dom, rozpoczynał budowanie swojego miejsca stałego, gdzie dokona się - używając słów Eliadego - „ustanowienie świata”:

nic nie może zacząć się, d ok o nyw ać si ę - dopóki nie zyskamy orientacji, ukierunkowania, a wszelkie ukierunkowanie implikuje obranie pewnego punktu stałego. Dlatego właśnie człowiek religijny stara się umieścić w „środku świata”. A b y żyć wświ e cie, trzeba go u stan owić, założyć (Eliade 1970, 54).

Widzimy, że mieszkaniec gór był nie tylko człowiekiem integralnym: zamknął w sobie i niejako pogodził wiele sfer - duchową, fizyczną, psychiczną, ale również na wskroś religijnym - dla niego świat to obszar doświadczania hierofanii i sacrum. Czy zatem możemy powiedzieć, że był wyznawcą religii kosmicznej? Wydaje się, że tak. Jasnym jest, że cała treść teologiczno-filozoficzna tetralogii osadzona jest w tradycji chrześcijańskiej i uzupełniona o liczne wierzenia ludowe, które były ściśle złączone z rytmem życia natury i płodnością ziemi. Już ten jeden aspekt może nas przenieść w krąg zagadnień związanych z religią kosmiczną. Jej głównymi wyznawcami byli bowiem „ludzie pierwotni”. Złączenie życia ludzkiego z życiem przyrody oraz doświadczenie świata jako kosmosu czy - w opozycji do niego - chaosu stanowić może bezpośrednie nawiązanie do głównych tez religii kosmicznej. Jak powiedzieliśmy sobie wcześniej, był Hucuł przekonany, że świat pełen jest pęknięć, tj. miejsc objawiających i ukazujących ślady Stwórcy. Mieszkaniec gór rozgraniczał dwa obszary: kosmos oraz chaos. Kosmosem była przestrzeń znana i bliska, pełna szczelin, które pozwalały na doświadczenie transcendencji, chaosem zaś były odległe, nieznane zakątki, pełne niebezpieczeństw. Jednak musimy pamiętać, że miejsca będące bezpieczną przystanią, spokojną i harmonijną, musiały uprzednio zostać odkryte, oswojone i niejako uświęcone. Świat określany jako „nasz” jest światem bliskim, w którym nastąpiło już objawienie się sacrum (Eliade 1970, 60).

Referując i zestawiając zagadnienia z podanego ćwiczenia oraz odnosząc je do tekstu Eliadego i Vincenza, uzupełniliśmy drugą kolumnę w tabeli. Przedstawia się ona następująco:

\begin{tabular}{|c|c|}
\hline STANISŁAW VINCENZ & MIRCEA ELIADE \\
\hline $\begin{array}{l}\text { 1. Przyroda: } \\
\text { - czas - fala wieczności } \\
\text { - przyroda i świat w ogóle przed- } \\
\text { stawiony jako kosmos } \\
\text { - odnawialność i rytm natury } \\
\text { - związek człowieka i ziemi } \\
\text { - miejsca doświadczenia kosmosu } \\
\text { i chaosu } \\
\text { - płodność ziemi }\end{array}$ & $\begin{array}{l}\text { 1. Religia kosmiczna: } \\
\text { • kosmos - przestrzeń } \\
\text { niejednorodna } \\
\text { • odnowa, ziemia } \\
\text { • człowiek żyje wg rytmu natury } \\
\text { • kosmos / chaos: przestrzeń nie- } \\
\text { jednorodna i jednorodna } \\
\text { - płodność ziemi }\end{array}$ \\
\hline
\end{tabular}


2. Budowa domu:

- miejsca objawione przez Stwórcę

- znaki - sen w miejscu, gdzie ma zostać zbudowany dom (jaki znak otrzyma człowiek)

- środki: miejsca - „pępki” (punkty stałe)

Myślę, że rozsypankę, którą zaproponowałam przy wprowadzaniu ustaleń dotyczących teorii Eliadego, można byłoby zastąpić mapą myśli, w której uczestnicy musieliby rozrysować (wraz z kolorowaniem) terminy i pojęcia z filozofii religii. Uaktywniłoby to i pobudziło percepcję studentów.

\section{Zakończenie to otwarta droga}

Dyskusja, która zrodziła się pod koniec zajęć, gdy już cała tabela była uzupełniona, pokazała, że utwór literacki stanowił doskonałą egzemplifikację pojęć z tekstu Eliadego. Cele zatem zostały osiągnięte: terminy z dziedziny filozofii religii zostały zrozumiane, zaś ich tropy i realizacje odnalezione w twórczości Stanisława Vincenza. Odkryliśmy świętą przestrzeń w Prawdzie starowieku, co pozwoliło nam również odmienić perspektywę spojrzenia na rzeczywistość. Filozoficzno-literackie ścieżki zaprowadziły nas do codzienności naszego życia. Pozostaliśmy zatem z refleksją nie tylko dotyczącą Stanisława Vincenza, Huculszczyzny czy Eliadego, ale również nas samych.

\section{Jak było naprawdę}

Zajęcia poświęcone „świętej przestrzeni” rzeczywiście się odbyły, jednak w nieco odmiennej formie... Powstały na potrzeby zajęć z dydaktyki akademickiej, podczas których każdy z uczestników (zatem również i ja) miał za zadanie przygotować konspekt i na jego podstawie poprowadzić zajęcia. Projekt przedstawiony w tym artykule jest wynikiem prac wykonanych już po uwagach i sugestiach prowadzącego i słuchaczy. W kilku słowach chciałabym przedstawić błędy, które popełniłam w trakcie wstępnych przygotowań, jak i podczas samego wystąpienia, tak aby świadomość ta mogła posłużyć jako materiał do metodycznej refleksji.

Zastanawiając się nad koncepcją zajęć poświęconych Vincenzowi i Eliademu, nie wzięłam pod uwagę kompetencji studentów. Przede wszystkim teksty, które wybrałam, były znacznie obszerniejsze niż te, które zasygnalizowałam na początku niniejszego artykułu, a co za tym idzie, pogłębiona lektura przed zajęciami była utrudniona. Nie pomyślałam też o tym, że warto powiedzieć studentom, na jakie aspekty podczas czytania powinni szczególnie zwrócić uwagę. Lektura sterowana konkretnymi sugestiami/ pytaniami na pewno ułatwia zadanie postawione przed słuchaczami. Kłopotliwe okazało się założenie, że zrozumienie tekstu filozoficznego nie będzie stanowiło wielkiego problemu. W praktyce było inaczej. 
Konspekt, który przygotowałam przed zajęciami, zakładał użycie metody dedukcyjnej - najpierw omawiamy tekst Eliadego, później Vincenza. Kolejność ta jednak była dyskusyjna. Kwestia ta łączy się ściśle z poziomem trudności i abstrakcyjności pojęć filozoficznych. Zrozumienie, czym jest religia kosmiczna czy człowiek religijny jedynie na podstawie tekstu filozoficznego, okazało się trudne. Warto zatem rozpocząć od analizy i interpretacji prozy, w której usłyszeć można echa religii kosmicznej.

Gdy rozmawiałam ze studentami na temat przeprowadzonych zajęć, ich reakcje były $\mathrm{w}$ dużej mierze pozytywne. W wielu $\mathrm{z}$ nich ciekawość poznawcza została rozbudzona, choć była też spora część, która z dystansem podeszła do zaproponowanego przeze mnie połączenia filozofii religii i literaturoznawstwa. Podejrzewam, że powodem, dla którego wdarł się ów sceptycyzm, była niechęć do rozważania zagadnień filozoficznych. Zajęcia pokazały, że interdyscyplinarne badanie literatury to droga, która może przynieść nowe spojrzenie na znaną nam już (lub nie) poezję czy prozę.

\section{Bibliografia}

Eliade Mircea, 1974, Sacrum, mit, historia, Tatarkiewicz A. (przeł.), Warszawa.

Kłoczowski Jan Andrzej, 2004, Między samotnością a wspólnota. Wstęp do filozofii religii, Tarnów.

Kostera Monika, Rosiak Agnieszka, 2008, Nauczyciel akademicki, Gdańsk.

Kwiatkowska-Ratajczak Maria, 2002, Metodyka konkretu, Poznań.

Nowaczyński Piotr, 2003, Mądrość Vincenza, Lublin.

Vincenz Stanisław, 2002, Prawda starowieku, Sejny.

Vincenz Stanisław, 1993, Outopos. Zapiski z lat 1938 - 1944, Wrocław.

Vincenz Stanisław, 1983, Po stronie dialogu 1, Warszawa.

\section{O Autorce:}

Sylwia Iwanek - doktorantka na Wydziale Nauk Humanistycznych Uniwersytetu Kardynała Stefana Wyszyńskiego w Warszawie; absolwentka filologii polskiej. Pisze rozprawę doktorską poświęconą zagadnieniu sakralizacji krajobrazu górskiego w twórczości Stanisława Vincenza, eseistyce Romana E. Rogowskiego oraz poezji Michała Jagiełły. Autorka artykułów i recenzji naukowych publikowanych m.in. w „Kontekstach”. Na co dzień pracuje jako nauczycielka języka polskiego w jednej z podwarszawskich szkół. 
